\title{
Den sønderjyske herredsfoged i senmiddelalderen
}

Et herredsfogedregnskab fra Sønder Gos herred 1474-75

\section{af Bjorn Poulsen}

Embedet wherredsfoged « forstås i almindelighed mest som en retslig stilling knyttet til herredstinget. Men $\mathrm{i}$ almindelighed var herredsfogeden lige så meget en embedsmand med brede administrative beføjelser, bl.a. som skatteopkræver. Disse opgaver havde herredsfogederne i nyere tid, og de kan spores helt tilbage i 1400-1500-årene. Arkivar, dr.phil. Bjørn Poulsen belyser her herredsfogedens opgave ud fra det tidligst bevarede herredsfogedregnskab i Sønderjylland.

Den senmiddelalderlige lokalforvaltning, som den udkrystalliserede sig i kongeriget Danmark og i hertugdømmet Sønderjylland i løbet af 1200-tallets sidste del og 1300-tallet, tog sit udgangspunkt $i$ en inddeling af landet $i$ adskillige len med hver sin borg. På borgene boede lensmændene med en skare af krigskarle og et civilt personale, der forestod bogføring, hushold og borgens almindelige drift. ${ }^{1}$ Borgens folk kunne imidlertid ikke alene overkomme styret af hele lenet. De måtte have lokale hjælpere for at sikre retsudøvelse, administration og opkrævninger ude i de enkelte herreder, som lenene bestod af. I takt med udbygningen af en administration, der var centreret omkring slottene, fremstod da fra det 15. århundredes begyndelse en stand af herredsfogeder, der bistod med at løse opgaver på herredsplan. ${ }^{2}$ I det følgende skal det forsøges at indkredse de funktioner, herredsfogeden i Sønderjylland fik i senmiddelalderen, først og fremmest ved hjælp af et enkelt regnskab.

\section{Herredsfogedens ansættelsesbrev}

En vej til at bestemme herredsfogedens hverv finder man i studiet af ansættelsesbreve eller bestallinger for enkelte fogeder. For 1400-tallets Sønderjylland ser breve af den type imidlertid ikke ud til at være bevaret, og man skal frem til næste århundrede for at finde dem. Lad os betragte to eksempler på disse ansættelsesbreve, idet vi begynder med hertug Frederiks (kong Frederik I's) bestalling for Karsten Grip fra $1528 .^{3}$

Ifølge dette brev ansætter hertugen Grip som herredsfoged på Ærø for 


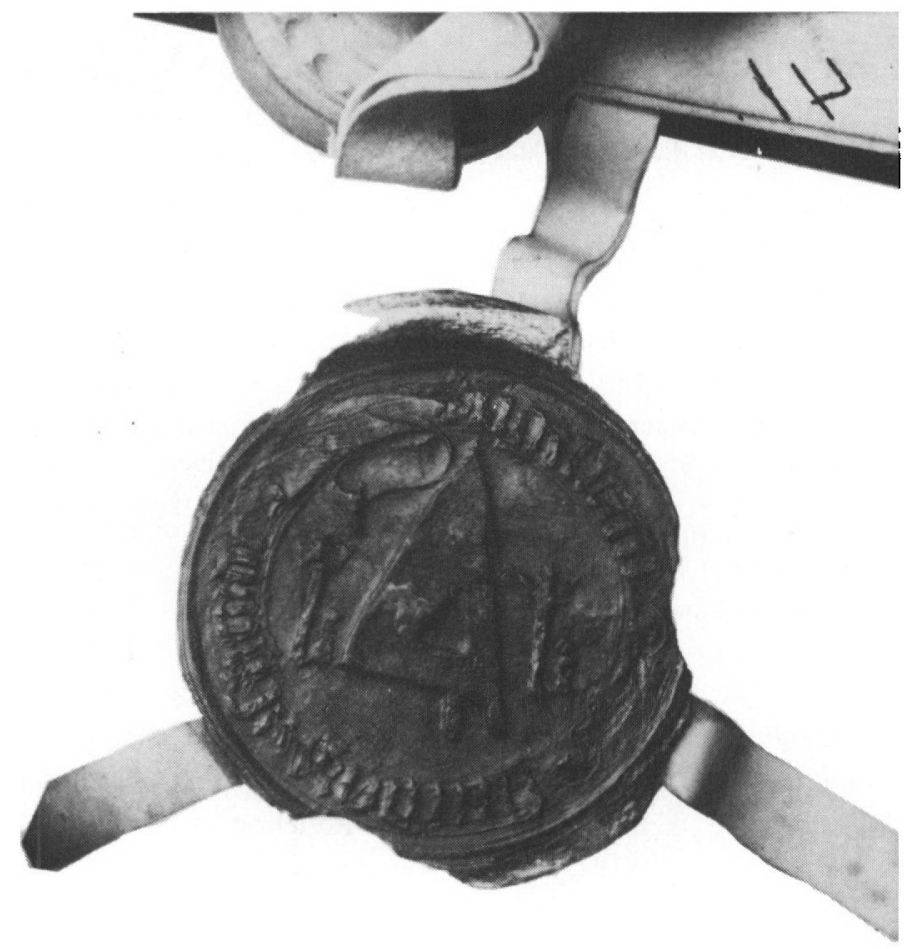

Seglet fra det herred, hvor Hans Brodersen var herredsfoged: Sonder Gos eller Sonder Gøs herred. Seglet viser et plovskar af jern, der fankeres af kronede minuskler (smd bogstaver). Seglet findes pd et brev fra 21, november 1577. Et plovskar fra middelalderen, der ligner seglets, er afbildet i Sonderjyske Arboger 1990 s. 11 . Foto Rigsarkivet.

livstid. Som stedfortræder for lensmanden i Sønderborg skal han først og fremmest sørge for, at alle de fyrstelige indtægter, landgilder, afgifter og bøder og andre årlige indtægter opkræves. Han skal være opmærksom på, at alt betales til rette tid til lensmanden i Sønderborg. Dernæst skal Grip holde opsyn med de kongelige skove og jagtdistrikter, så de ikke forhugges. Til gengæld for pligterne får Grip så lov til for livstid at bo gratis på en gård, kaldet "Ladegård «, og bruge dens agre, enge og græsning. I skovene må han hente brændsel til eget forbrug, og han må frit slippe sine svin ud, når der er olden. Åbenbart afløser Grip en tidligere foged på øen, som har haft titlen "landfoged «, og det er alle hans privilegier, han overtager.

Et yderligere ansættelsesbrev gælder Matias Paysen, der 9. februar $1562 \mathrm{blev}$ udnævnt af hertug Adolf til herredsfoged i Husum, Sønder Gos herred m.m. ${ }^{4}$ 
Brevet indledes med en bekræftelse af, at Paysen, indbygger i flækken Husum, er antaget til herredsfoged sammesteds. Han skal søge at fremme hertugens bedste på alle måder, høre undersåtternes klager, nedskrive disse klager i et "register« og derefter lade enhver få sin ret. I sin retsudøvelse må han ikke tage hensyn til venskab eller modtage gaver. De afgifter han årligt opkræver, såvel de faste som de svingende skal indføres i et tydeligt regnskab. Til gengæld for sit arbejde skal herredsfogeden nyde, hvad alle hans forgængere i embedet har haft, undtagen fra husmændene, "die Kotenern«, hvis afgifter hertugen ønsker selv at nyde godt af. Bestallingen slutter med en ordre til alle indbyggere i flækken Husum og beboerne i Sønder Gos herred, Hatstedmark og Lundenberg herred om at ære, agte og adlyde Paysen i hans egenskab af herredsfoged.

De to breve viser tydeligt herredsfogedens funktion som lensmandens forlængede arm i lokalsamfundet. Som det fremgår, stod han for afgifters indsamling, for opretholdelse af fyrstelig ejendom, for rettens opretholdelse. Til gengæld nød han så visse privilegier. Der var tale om en betydningsfuld formidlerstilling, og studiet af Grips og Paysens levnedsløb afslører da også som normalt, at det ikke var den jævne mand, der fik embedet.

\section{Et regnskab fra $1474 / 5$}

I ansættelsesbrevet for Matias Paysen nævntes det, at de indkommende indtægter skulle indføres i »ein klar Register und Verzeichnis«, et tydeligt register og fortegnelse. Det er indlysende, at sådanne bevarede regnskaber vil kunne føre os langt videre i forstålsen af herredsfogedens arbejde, end de blotte ansættelsesbreve formår. Nu er herredsfogedernes optegnelser desværre overordentlig sjældne. Blandt de ældste nordslesvigske er Slogs herredsfogeds regnskab fra anden halvdel af 1600-tallet. ${ }^{5}$ På næsten mirakuløs vis har dog et langt ældre sydslesvigsk regnskab fra 1400-tallet overlevet århundrederne og opbevares nu i Rigsarkivet. ${ }^{6}$

Dette sjældne stykke er som normalt i senmiddelalderen ført på foldede folioark og består af 6 beskrevne sider. Det starter med overskriften $» D y t$ naschreu(en) hebbe ik hans broder $B$ va(n) der borgh gottorpp uthgeuen und dar sent, und ock entfang(en) wan Anno 74 wente int Jar 75 upp paschen«, altså: der er tale om dels indtægter, dels ydelser, som en Hans Brodersen har haft til borgen Gottorp i tidsrummet mellem påsken (14)74 og påsken (14)75. Sidst i regnskabet, der begynder i påskeugen 1474 og sluttes 8 dage før påsken 1475 , betegnes Hans Brodersen »herredsfoged i Sønder Gos herred «, og det fremgår også, at der blandt de registrerede indbetalinger var ydelser fra Hatstedmark. Ud fra kilden selv kan man følgelig udlede, at der er tale om 
en herredsfogeds årsregnskab for Sønder Gos herred og Hatsted mark fra ca. 10. april 1474 til ca. 18. marts 1475.

Regnskabet, der er beregnet i mark lybsk (à 16 skilling), deler sig i udgiftsfortegnelse, indtægtsfortegnelse og endelig i revisionens påtegning. Inden for udgifterne finder man tre undergrupper, nemlig ydelser til Gottorp slot, udgifter $\mathrm{i}$ forbindelse med en rejse til Helgoland og løn til møllere. Lad os betragte de udgifter, som herredsfogeden Hans Brodersen havde.

\section{Hans Brodersens udgifter}

Det fremgår indledningsvis, at herredsfogeden havde en rolle som forsyner af husholdningen i Gottorp. Fra borgen kunne man rekvirere naturalier hos ham. I løbet af regnskabsåret blev det til følgende sendinger (tab 1).

Tab. 1. Sendinger til Gottorp 1474/75.

\begin{tabular}{ll}
\hline Vare & Mængde/Værdi \\
\hline lam: & 17 lam for $4 \mathrm{mk} 4 \mathrm{sk}$ \\
kabeljau: & for $27 \mathrm{sk}$ \\
talg: & for $3 \mathrm{mk} 15 \mathrm{sk}+27 \mathrm{l} / 2 \mathrm{sk}+1 / 2$ td for $3 \mathrm{mk} \mathrm{15} \mathrm{sk}+4 \mathrm{mk} 11$ \\
& sk \\
tjære og beg: & 1 tønde af hver for ialt $4 \mathrm{mk} 4 \mathrm{sk}$ \\
gryn: & for $20 \mathrm{sk}$ \\
sennep: & 1 tønde for $1 \mathrm{mk}$ \\
hamburgsk øl: & 1 læst for $9 \mathrm{mk}$ \\
\hline ialt: & 30 mark 7 skilling \\
\hline
\end{tabular}

Med vogn eller drifter af levende dyr har herredsfogeden altså sendt varer, der opstod behov for i borgkøkkenet, samt tjære og beg, måske til kongelige skibe i Østersøen. Det er sandsynligt, at tjære, beg, sennep og hamburgsk øl var købt i Husums havn.

Det andet sted, hvortil der blev leveret, var Pelworm, der på dette tidspunkt udgjorde en del af øen Nordstrand, og der må jo derfor være benyttet skib for at få godset frem. Der var tale om transporter af kul, dvs trækul. I tre omgange, den ene gang formentlig 13. oktober 1474, sendtes for 17 skilling, 3 mark 5 1/2 skilling og 24 skilling kul. Lensmanden med følge har sikkert opholdt sig her på „gæsteri«, og herredsfogeden har måttet hjælpe med brændsel til varme.

En række helt specielle leverancer fremkom i forbindelse med wrejsen til Helgoland «. Vi kan ret klart følge ekspeditionen. Der tales om en høvedsmand 
ved navn Hans Andersen, der fik 3 mark til tæring. Med sig havde han 7 svende, der lønnedes således: 2 mark (1 person), 1 1/2 mark ( 3 personer), 1 mark ( 1 person), 12 skilling ( 1 person), 8 skilling ( 1 person). For selve sejladsen stod en styrmand, der modtog 2 mark. De ni mand skulle selvfølgelig have noget at spise, og til proviant fik de to slagtede okser til 6 mark, humle for 31 skilling, eddike for 6 skilling, sild for 4 skilling, 7 tønder groft ol til 5 mark 4 skilling samt uspecificeret øl for 12 skilling. På selve skibet var der behov for at reparere bommen (»de bame«) for 7 skilling, og tov for 3 mark 6 skilling var vel også til brug her. Endelig skulle lensmanden efter ekspeditionen åbenbart have gods hjem igen fra Helgoland med en ekstra båd; det kostede 6 mark 4 skilling i fragtpenge.

Om formålet med rejsen til Helgoland oplyser regnskabet intet, og man må ty til andet kildemateriale for at forstå sagen. I 1356 havde kong Valdemar opført en forskansning på klippeøen i Vesterhavet; ${ }^{7}$ men i det følgende århundrede er der få konkrete spor af, at Slesvigs landsherrer udøvede deres højhedsret her. Den ekspedition, der omtales i regnskabet, markerer antagelig en tidlig fase af en ny praksis, der indarbejdedes i sidste tredjedel af 1400-tallet. Hvert år tog nu en foged med væbnede folk til øen for at opkræve afgifter i fisketiden. Da der på Helgoland samledes over 2000 fiskere fra hele Vesterhavsregionen, var der var mange penge at tjene for fyrsten ved at opkræve bodepenge, årepenge, olpenge $\mathrm{og}$ andre afgifter. ${ }^{8}$ Husums havn dannede det naturlige udgangspunkt for skattetogterne, og det blev derfor den stedlige herredsfoged, der kom til at stå for fødevareforsyninger til fyrstens opkrævere.

En vigtig del af lensindtægterne var mølleafgifter. Hans Brodersens regnskab viser, at det påhvilede herredsfogeden at sørge for fire fyrstelige møllers vedligeholdelse inden for sit område. ${ }^{9}$ Der omtales flere reparationer på dem. Til en vindmølle, som lå i Husum, var der behov for 2 fade osemund, svensk jern, som Brodersen betalte 8 mark for. På en vindmølle i Husum reparerede 3 tømrere møllerenden, »dat gruntwark«, og fik for det en tønde øl til 9 skilling samt en løn på 2 mark 4 skilling. De samme håndværkere var også ved møllen i Agebro, hvor de ordnede møllehjulet og tjente 30 skilling og igen en tønde øl. Møllerne var lønnede folk, der skulle have en årsløn, og også det stod Brodersen for. Tre møllere i Husum, Henrik, Boye og Hans fik hver 18 mark årligt, mens mølleren på det mindre anlæg ved Agebro kun modtog 16 mark.

En udgift, der umiddelbart er gådefuld, forekommer i to poster, hvor der tales om »min herres«/»herskabets« pande. Det kostede det betragtelige beløb af 11 mark at reparere den, og 4 skilling at transportere den fra Lübeck til Husum. Panden dukker igen op på regnskabets indtægtsside, hvor man kan læse, at der kom 3 mark »uth der bussen van der herschupp pannen«, fra herskabets pandes bøsse. ${ }^{10} »$ Pander « træffer man i denne tid oftest $i$ forbindelse 

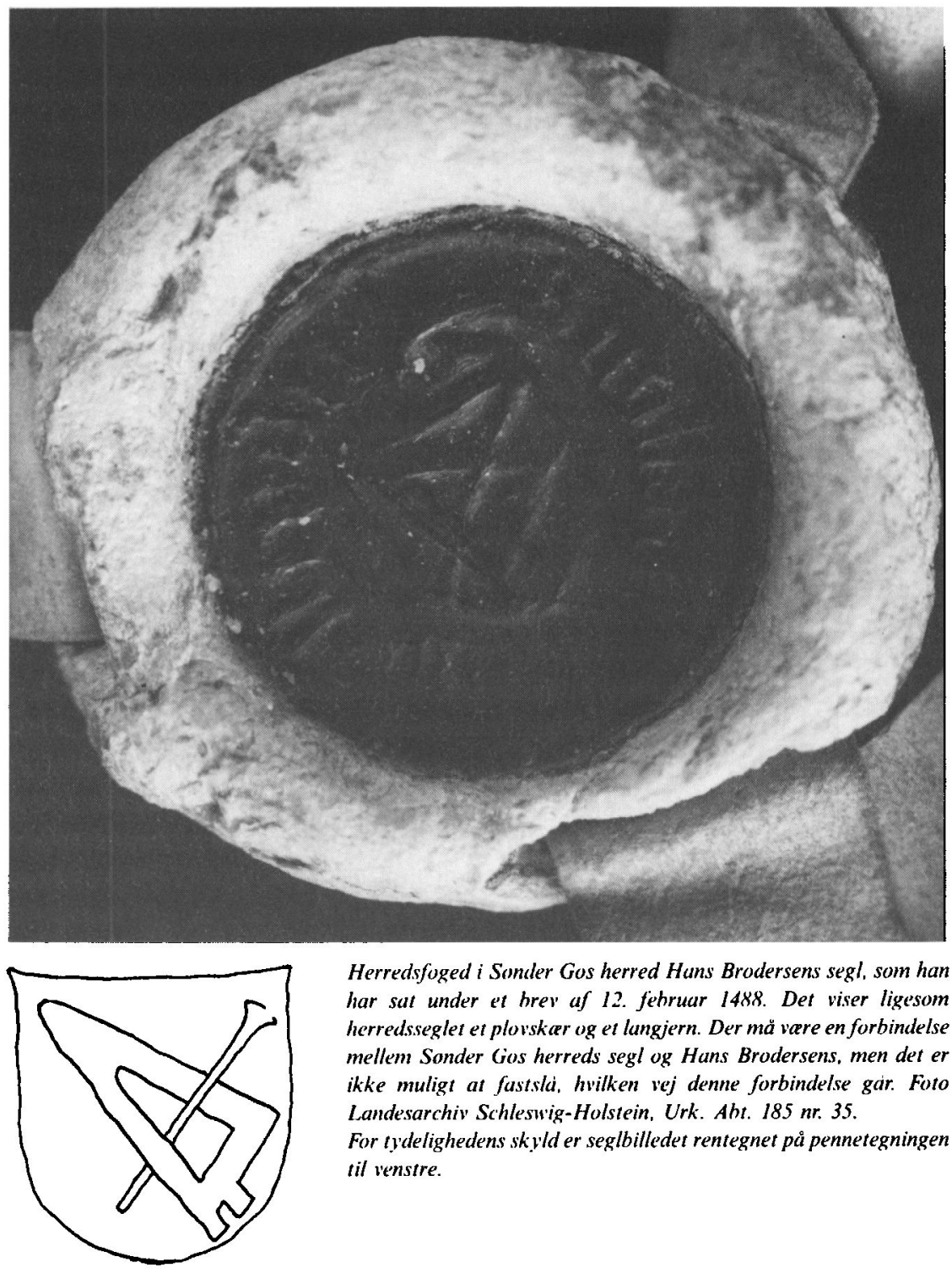

Herredsfoged i Sonder Gos herred Hans Brodersens segl, som han har sal under et hrev of 12. fehruar 1488. Det viser ligesom herredsseglet et plovskar ug et langjern. Der mà vare en forbindelse mellem Sonder Gos herreds segl og Hans Brodersens, men det er ikke muligt at fastsla, hvilken vej denne forbindelse gar. Foto Landesarchiv Schleswig-Holstein, Urk. Aht. 185 nr. 35.

For tydelighedens sky/d er seglbilledet rentegnet på pennetegningen til venstre.

med saltudvinding, hvor de benyttedes til udsydning af saltet. Da vi ved, at den slesvigske hertug senere havde en saltsydningsbod, er det rimeligt at forestille sig, at der er tale om investeringer $i$ en sådan.

Som de sidste udgifter i regnskabet finder man herredsfogedens egen løn: 
"20 mark løn for min tjeneste« og en notits om, at lensmanden Peter von Ahlefeldt har modtaget 139 mark lybsk.

Det var udgifterne. Lad os herefter se på herredsfogedens indtægter.

\section{Hans Brodersens indtægter}

Hans Brodersen havde som myndighedsområde Sønder Gos herred og det kongelige birk Hatsted mark. Begge territoriale enheder var overvejende beboet af rige selvejerbønder, som det påhvilede Brodersen at få til at betale de skyldige summer. Bønderne betalte hovedparten af deres pengeafgifter $i$ to store omgange. Forst på året, i begyndelsen af maj, kom Valborgs-beden, som er nævnt ved navn i herredsfoged-regnskabet; senere på overgangen mellem september og oktober opkrævedes en skat, som andre kilder giver os navnet på, Mikkelsbeden. "Skatterne indkom ifølge regnskabet med følgende summer (tab. 2).

Tab. 2. Årlige »heder« 1474.

\begin{tabular}{lll}
\hline Område & Valborgsbede (maj 1474) & Michaelisbede (sept/okt 1474) \\
\hline S. Gos hd. & 21 mark & 71 mark \\
Hatsted mark & 9 mark & 60 mark \\
\hline
\end{tabular}

Det er ganske tydeligt, at efterårets skat, der betaltes efter, at høsten var $\mathrm{i}$ hus, slagtningen foretaget og okserne solgt, var den, der gav mest. På den anden side viser valborgsbedens omfang, at landbrugssamfundet bestemt ikke var tørlagt for rede penge om foråret. Til disse mere omfattende betalinger føjede sig tre mindre afgifter, der havde deres rødder i Valdemarstidens skatter, og som alle ifølge regnskabet beløb sig til 8 mark, nemlig "stud «, »tjeneste" og »leding".

Helt blottet for fæstebønder under landsherren var Sønder Gos herred heller ikke. Det kom til udtryk ved en post, der registrerer en 14 marks indtægt, betalt af fresterne, »den lansten«, i Immingsted i Svesing sogn. Immingsted by med dens halve snes fæstere var erhvervet af hertug Adolf VIII fra væbneren Jørgen Lund i $1438 .{ }^{12}$ Interessant nok kan man iøvrigt se, at fæsternes afgift vedblev at være konstant op gennem 1500-tallet, hvor inflationen ellers havde reduceret dens værdi betragteligt. ${ }^{13}$ Fæsterne i Immingsted betalte i 1474 yderligere 3 mark wvor de loghe«, dvs. for udnyttelsen af den lund, der lå ved landsbyen. ${ }^{14}$ Lejepenge fra jordstykker forekom også. Der registreredes 4 mark "landgelt«, som betaltes af landsbyen Vitbæk i Ostenfeld sogn og 7 mark "wiskhur» (engleje) fra Mildsted. 
Kun i et tilfælde opkrævede herredsfogeden en bøde; den androg 10 mark. Lige så isoleret står tre andre poster i regnskabet. Hans Andersen, der vel var høvedsmanden fra Helgolandtogtet, betalte i guldmønter 3 'rhinske gylden' og 2 af de ringere 'postulatsgylden', der prægedes henholdsvis af de 4 rhinske kurfyrster og i Tyskland og Nederlandene af postulerede bisper, dvs. bisper, der var kaldt til bispedømmet, men ikke indsat af paven. Herman Sniddeker, altså vel en snedker, betalte 4 1/2 mark for en tønde smør. Og endelig figurerer så de allerede nævnte 3 marks indtægt fra herskabets pandes bøsse.

Hermed er alle herredsfogedens udgifter og indtægter nævnt.

\section{Hans Brodersens budget}

18. marts $\mathbf{1 4 7 5}$ gjorde lensmanden på Gottorp slot, den erfarne administrator Peter von Ahlefeldt, regnskabet op med Hans Brodersen. Resultatet blev følgende (tab. 3).

Tab. 3. Regnskab for herredsfoged Hans Brodersen fra ca. 10/4 1474 til ca. 18/3 1475. UDGIFTER

Køb og reparation $66 \mathrm{mk} 2 \mathrm{sk}$

Helgolandsrejse $\quad 38 \mathrm{mk} 5 \mathrm{sk}$

Lønninger

$90 \mathrm{mk}$

INDTÆGTER

Diverse

$337 \mathrm{mk} 14 \mathrm{sk}$

$194 \mathrm{mk} 7 \mathrm{sk}$

Til lensmand i regnskabsår

$139 \mathrm{mk}$

Ialt

$333 \mathrm{mk} 7 \mathrm{sk}$

Overskud

$4 \mathrm{mk} 7 \mathrm{sk}$

337 mk 14 sk

På det smukt afstemte regnskab finder man to udbetalinger til lensmanden. Den store på 139 mark må tolkes som en udbetaling efter en foreløbig opgørelse sent på regnskabsåret. Denne opgørelse var da så præcis, at lensmanden måtte nøjes med det minimale beløb af 4 mark 7 skilling, som han noterede, at Brodersen betalte med rede penge - og »dar mede slate(n) dyt jege(n)wardighe register«, dermed slutter nærværende regnskab. Nettooverskuddet, som gik videre til lensslottets administration, var disse to beløb lagt sammen, altså 143 mark 7 skilling. De øvrige penge må betragtes som brugte til administration på herredsfogedniveau - omend for en dels vedkommende til direkte gavn for den højere administration.

Sætter man herredsfogedens budget i forhold til lensmandens, viser det sig, at det ikke er ubetydeligt. I regnskabsåret 1489/90 havde lensmanden på Gottorp ca. 2300 mark i indtægt og ca. 2800 mark i udgift. Herredsfogeden 
havde et regnskab, der udgjorde henved en tiendedel af hans herres. Alene dette faktum giver anledning til at overveje nogle hævdvundne forestillinger om herredsfogedens funktion og kvalifikationer $\mathrm{i}$ senmiddelalderen. Hans Brodersens regnskab udgør tydeligvis en fremragende kilde til belysning af herredsfogedens generelle stilling i senmiddelalderen, men samtidig er det jo også en individuel kilde, nemlig til Hans Brodersen og hans virke. Lad os, inden vi vender os til det bredere, se på manden bag regnskabet.

\section{Hans Brodersen som herredsfoged}

Hans Brodersen må betegnes som tilhørende lavadelen. I 1461 fik han fribrev af Christian I; han skulle for fremtiden tjene fyrsten som andre adelige. ${ }^{15}$ Utvivlsomt har han og hans slægt befundet sig i en konkurrencesituation med den mand, der på dette tidspunkt var herredsfoged, Tete Andersen. ${ }^{16} 1464$ lykkedes det Hans at fortrænge Tete fra embedet for selv at indtage det, og 15. juni 1464 træffer vi ham i funktion. Han var sammen med en lang række fornemme personer med til at afsige en kendelse om den rette grænse mellem Sønder Gos herred og Svavsted sogn. Igen i 1466 underskrev han sig wherredsfoged i Sønder Gos herred «, da han bevidnede, at kollegaen fogeden Tete Veddersen fra Ejdersted, Everschop og Utholm havde stiftet en sjalemesse for sine to afdøde sønner. ${ }^{17}$ I en alliance med grev Gerhard genvandt Tete Andersen i 1467 herredsfogedposten, men tabte så alt ved at tilslutte sig oprøret mod Christian I i 1472. Fra da af og til 1489 fungerede Hans Brodersen uforstyrret i hvervet som herredsfoged. Som embedsområde fik han nu ikke kun selve Sønder Gos herred. Under sig fik han også, som det fremgik af 1474-regnskabet, Hatsted mark, og da Husum med oprøret 1472 fortabte sine privilegier, blev byfogedens hidtidige funktioner også overdraget Hans Brodersen. Til støtte for hans position overdrog kongen ham i 1473 en af oprørernes ejendom i Hatsted mark. ${ }^{18}$

I de følgende år ser vi, at han havde hus i Husum; at han deltog, når der $\mathrm{i}$ denne by blev nedsat skibsretter og ved de almindelige tinghandlinger $i$ herredet. Hvad der først og fremmest kaster lys over hans virke er imidlertid et bevaret regnskab for Gottorp len for perioden 9/12 1489 til 11/8 1490. Dette regnskab, der ser sagen fra lenets side, viser igen Hans Brodersen $i$ hans egenskab af lensmandens aktive agent (tab 4).

Disse varer, kreaturer, smør og korn blev købt op af Hans Brodersen og sendt videre til borgen. Der er altså tale om poster, der ligner dem, der figurerede $i$ herredsfogedens eget regnskab. På den anden side er det næppe identiske poster. Omkring 300 mark summer udlæggene sig til i 1489/90, et 
Tab. 4. Hans Brodersens køb til Gottorp 1489/90.

\begin{tabular}{ll}
\hline Vare & Pris \\
\hline 30 fede okser & $134 \mathrm{mk} 3 \mathrm{sk}$ \\
43 lam & $10 \mathrm{mk} 12 \mathrm{sk}$ \\
lam & $48 \mathrm{mk} 11 / 2 \mathrm{sk}$ \\
17 fede gamle lam & $12 \mathrm{mk} 12 \mathrm{sk}$ \\
36 fede lam & $24 \mathrm{mk} 5 \mathrm{sk}$ \\
38 lam & $10 \mathrm{mk}$ \\
$1 / 2$ lrest smør & $36 \mathrm{mk}$ \\
havre & $10 \mathrm{mk}$ \\
2 købmandslæster havre & $12 \mathrm{mk}$ \\
\hline
\end{tabular}

beløb, der er langt større end de henved 30 mark 7 skilling, der noteres $i$ Brodersens eget regnskab fra 1474. Det ser ud til, at beløbene i 1489/90 straks er refunderet af lensadministrationen, og de udgør altså et supplement til tallene $\mathrm{i}$ herredsfogedens årsregnskab. En enkelt transaktion magtede Brodersen ikke alene, men tog skriveren fra Gottorp slot til hjælp. Det drejede sig om købet af 200 tønder byg, som erhvervedes i Husum for 100 mark, rimeligvis polsk transitkorn ført fra Flensborg til Husum. ${ }^{19}$ Et videre studium af regnskabet antyder, at der muligvis var sket en centralisering af lenets økonomiske forvaltning i perioden 1474 til 1489/90. Man ser nemlig, at der i lensregnskabet $1489 / 90$ er noteret udgifter til møllernes reparation og til lønudgifter til møllere i Sønder Gos herred. Hvor disse udgifter i 1474 afholdtes af herredsfogeden, ser det ud til, at de en snes år senere blev bestridt af lenets styrelse. Interessant i denne forbindelse er det også, at det bevarede lensregnskab ikke indeholder en samlet mellemregning eller årsopgørelse med herredsfogederne. Manglen på yderligere regnskabsmateriale vanskeliggør dog videre slutninger om eventuelle indskrænkninger $\mathrm{i}$ herredsfogedens økonomiske selvstændighed.

\section{Herredsfogedens funktioner}

Herredsfogedregnskabet fra 1474 er som kilde til rækkevidden af herredsfogedens administrative beføjelser af allerstørste betydning. Regnskabet dementerer grundigt den gængse mening, at herredsfogedens embede i det væsentlige skulle være knyttet til herredstinget. ${ }^{20}$ Denne opfattelse viser sig - når vi generaliserer ud fra det her undersøgte eksempel - kun at hvile på, at de kilder, hvori vi normalt træffer herredsfogeder, netop er tingsvidner udstedt på herredstinget. Det bevarede regnskab gør det tydeligt, hvordan herredsfogeden indtog en central plads i lokalsamfundet som opkøber for landsherren, som opkræver af afgifter og i det hele taget som statens repræsentant. 


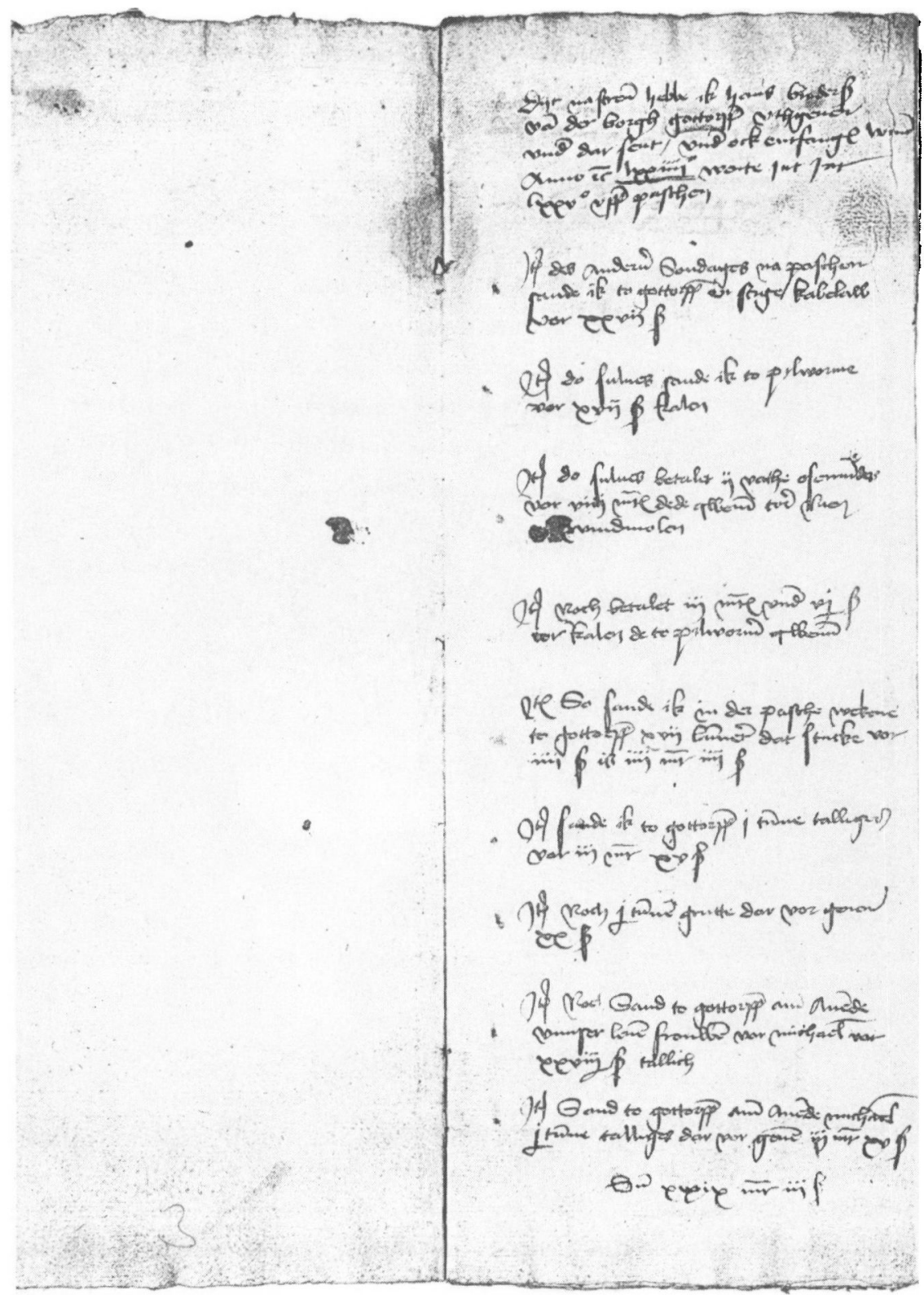

Forste side af Hans Brodersens regnskah fra 1474/5, der starter med en oversigt over, hvad der er sendt til Gottorp slot. 
En grundig skoling i regnskabsføring var nødvendig udover kendskab til loven, og disse færdigheder tillod på alle måder herredsfogeden at fungere som lensmandens aktive agent.

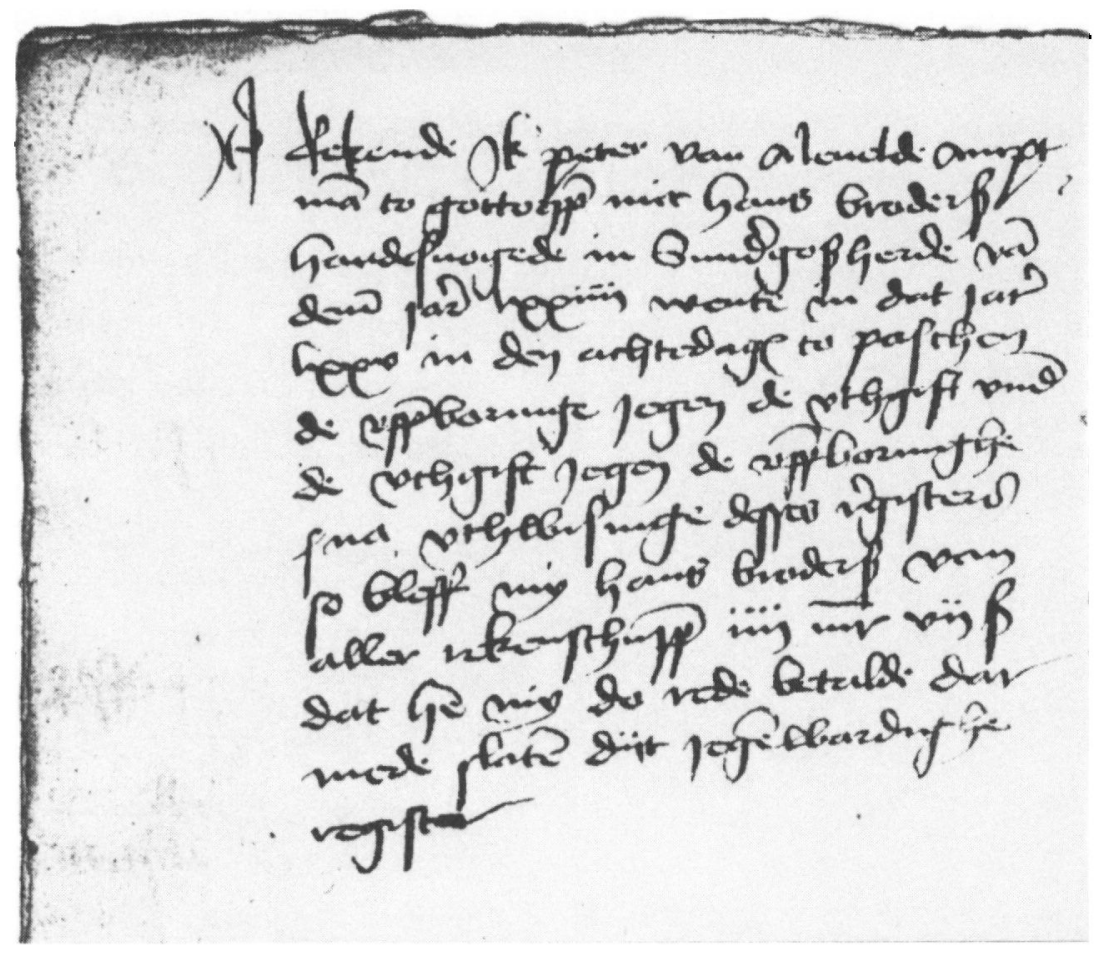

Revisionens påtegning på sidste side af Hans Brodersens regnskab fra 1474/5. Lensmanden på Gottorp slot Peter von Ahlefeldt ger indiagt, udgift og overskud op og noterer: "Dermed slutter narvarende regnskah".

Men herredsfogeden kan ikke unuanceret betegnes som lensmandens forlængede arm. Studerer vi regnskabsføreren Hans Brodersens historie, bliver det tydeligt, at lensmanden nok udnæunte herredsfogeden, men at det ikke skete frit. Striden mellem Tete Andersen og Hans Brodersen eksemplificerer, hvordan det lokale vestslesvigske samfund var domineret af herskende storbondeslægter, som den centrale magt ganske sikkert var nødt til at indgå i alliancer med, hvis autoriteten skulle respekteres. Lensmanden sluttede det nødvendige forbund med de stærkeste grupper eller enkeltpersoner i lokalsamfundet. At disse forbindelser bidrog kraftigt til at give herredsfogedembedets indehavere 
virkelige magtpositioner er givet. Direkte feudale forhold træder frem i fyrstens tildeling af gods i Hatsted mark til Brodersen.

Man ser, at den senmiddelalderlige lokaladministration langt fra var simpel og primitiv. Det var ikke et system, hvor lensmanden på sit høje slot stod over for en bondebefolkning, han skulle administrere og presse ydelser ud af. Nej, lensmanden, staten, trængte langt ned $\mathrm{i}$ det lokale samfund og fandt sine forbundsfæller her. På herredsplan arbejdede hans dynamiske underherre, herredsfogeden, der havde vide rammer for sit arbejde, og som funderede sin betydning på dobbeltpositionen som både fyrstens og de lokales repræsentant. Dobbeltstillinger længere nede $\mathrm{i}$ systemet besad videre de såkaldte "rekenslude « / "rekensmänner«, som vi møder ihvertfald fra 1400-tallets anden halvdel. ${ }^{21}$ Disse lokale repræsentanter for fyrsten sørgede i de enkelte bebygelser for administration og opkræuning. De udgjorde de lavest sanktionerede statsadministratorer, men igen må man spørge sig, om de ikke under sig styrkede en gruppe af mellemmænd, nemlig de enkelte husstandes overhoveder, der $\mathrm{i}$ stigende grad $\mathrm{i}$ forhold til deres hushold kom til at repræsentere og forvalte fyrstemagtens administration og krav i forhold til familie og hushold.

Endnu befandt man sig $i$ et middelalderligt magtsystem. På landet var magten stadig i høj grad samlet hos herremænd, hos gilder, hvis medlemsskare gik på tværs af egnene, hos lokale slægtsgrupper. Men den centralisering af fyrstemagten, som sætter sig igennem i løbet af det 16. og 17. århundrede, og som bryder sig en vej gennem samfundets traditionelle hierarkier, finder en af sin forudsætninger $\mathrm{i}$ herredsfogedembedets udbygning $\mathrm{i}$ det foregående tidsrum.

NOTER

1. Jfr. B. Poulsen: Slesvig for delingen i 1490. Et bidrag til senmiddelalderens finansforvaltning. Historisk Tidsskrift, 90,1990 , s. 38-63.

2. Ang. herredsfogeder se generelt William Christensen: Dansk Statsforvaltning i det 15. Århundrede. Kbh 1903, s. 249-259. Peter Skautrup: Herredstinget og dets Funktion indtil Enevælden. Jyske Samlinger, 5. Rk., 4, 1938, s. 265-76. Thomas Otto Achelis: Von Hardesvögten und Hardesschreibern. Schleswig-Holsteinische Anzeigen, 1950, Teil A, Nr 5, s. 103-109. Ernst Joachim Fürsen: Der Hardesvogt im Herzogtum Schleswig, unter besonderer Berücksichtigung des Zeitraumes von 1721-1867. Kiel 1973 (diss.). Thelma Jexlev: Herredstingene i middelalderen. En vigtig lokal faktor og en endnu vigtigere lokalhistorisk kilde. Slægter. Skjolde. Steder. Festskrift til Knud Prange 6. juni 1990. Odense 1990, s. 171-181.

3. Stemann: Geschichte des öffentlichen und Privat-Rechts des Herzogthums Schleswig. III, Kbh 1867, s. 202.

4. Stemann: Geschichte des öffentlichen und Privat-Rechts des Herzogthums Schleswig. III, Kbh 1867, s. 252. 
5. LA, Aabenraa, Små embeders arkiver. Slogs herreds herredsfoged. 1652-75. Slogs herreds herredsregnskab. Et privatregnskab fra ca. 1510 fort af herredsfoged i Sønder Gos herred Walke Widdesen er beskrevet Bjørn Poulsen: Bondens Penge. Studier i sønderjyske regnskaber 14001650. Odense 1990, s. $78 \mathrm{ff}$.

6. RA. København, Slesvigske og holstenske regnskaber før 1580 . Kongens arkiv, rev. regnsk. I, 2, Gottorp amts regnskaber 1438-1510. Regnskab over indtægt og udgift af Sønder Gos herred og Hatsted mark 1474-5.

7. Dipl Dan III, 4, nr. 463.

8. B. Poulsen: Land - By - Marked. To økonomiske landskaber i 1400-tallets Slesvig. Flensborg 1988, s. 178-180.

9. Jfr B. Poulsen: Land - By Marked, s. 66-67.

10. Udgift: 1) Item geue ( $n$ ) vor mynes hern panne (n) to hußem to beternde 11 mrk. 2) Item 4 \& to vore de sulue $(n)$ pa(n)ne(n) va(n) lub to hußem. Indtægt: Item 3 mrk uth der bussen va(n) der herschupp $p a(n) n e(n)$. Hvis der har været tale om en saltpande eller kedel, har den formentlig varet af jern.

11. Ordet »bede« betegnede oprindelig de ekstraordinære skatter, som kongen måtte »bede« landets indbyggere om, når der var behov herfor.

12. Registrum König Christian des Ersten, udg. af Georg Hille, Kiel 1875, s. 532, nr 468. Jfr. B. Poulsen: Land - By Marked, s. 232.

13. Jfr. LAS. Abt 168, Gottorp Amtsrechn. 1554.

14. Jfr. Otto Mensing: Schleswig-Holsteinisches Wörterbuch, III, Neumünster 1931, sp. 502. Skovstykket nævnes også i 1496 Repertorium II, nr. 8204. Jfr. C. v. Stemann: Urkundliche Beiträge zur Geschichte der Herzogthümer Schleswig und Holstein. Husum 1879, s. 24, 45, 46.

15. Registrum König Christian des Ersten, s. 556, nr 479.

16. Se nærmere B. Poulsen: Land - By Marked, s. 61-2.

17. Repertorium II 2088 ( = Staatsbürgerliches Magazin VIII, s. 682).

18. Registrum König Christian des Ersten, s. 413, nr. 317.

19. "Item vor 200 td garsten de t. $8 \beta$ gekofft laten to hußum und kofften hans broders $\beta$ und de sch(r)iuer als ick de borg ersten von mynen $g$ hern entfangk und a(n)namede... Is $100 \mathrm{mrk}$.

20. Anf. arb. W. Christensen: Dansk Statsforvaltning, s. 252: "Hvad Herredsfogedernes Embedsvirksomhed angaar, er den, să vidt vi kender den aldeles overvejende knyttet til Herredstinget «. Herredsfogedens omfattende administrative befajelser er derimod kendt fra 1700-årene, se Lars N. Henningsen i Ensted sogns historie, 1987 s. 77.

21. "Rekenslude« træffer man f. eks. 1481 i Flensborg len (Landesarch., Schleswig, Abt 400.1, nr 312. Regnskab for Flensborg len). I 1500-tallet og senere nævnes de ofte. 